\title{
Development of Models for Fishery Resources and Production Statistics of West Bengal, India
}

\author{
Ambalika Ghosh ${ }^{1 *}$, BK Mohapatra ${ }^{2}$ and AK Roy ${ }^{3 *}$ \\ ${ }^{1}$ Department of Fishery, Govt. of West Bengal, India \\ ${ }^{2} I C A R-C I F E, G N-B l$, Salt Lake, India \\ ${ }^{3}$ College of Fisheries, CAU, India
}

Submission: June 8, 2017; Published: October 12, 2017

*Corresponding author: AK Roy, Department of Fishery, Govt. of West Bengal, India, Tel: 919230011361; Email: akroy1946@yahoo.co.in

\begin{abstract}
West Bengal is rich in Inland Fishery Resources. Ponds and tanks dominate with 90.62 parent resources under culture. Overall $87.56 \%$ of total potential resource is utilized for culture leaving another $12.44 \%$ for bring under culture. Total area under of River, Canal/ Khal and Beal / Boars of West Bengal is 279569.31 ha. River occupies 58\% of total area followed by canal / Khal (27\%) and Beal / boar (15\%). Fishermen constitute about 3.3 percent of total population of 9.13 crores in West Bengal. Fisheries are next to agriculture in terms of providing employment and food supply. Fish is an important source of quality protein and cheaper in cost compared to other sources of animal protein There is a gap of 5.2lakh ton in Fish Demand and Supply in West Bengal. Under the situation it is thought appropriate to quantify the exact nature of fluctuating trend of each of the demand and production from various sectors. Therefore, based on secondary authentic statistics for the first time, it is attempted in-depth analysis of fishery resource and production statistics trends of West Bengal, a major fish producing state of India with highest per capita consumption. Developed the following Prediction models on sector wise production and fish demand in the state of West Bengal. Prediction Model Inland fish production: Yest $=8+0.467 X ; R^{2}=0.894$; Marine fish production: Yest $=1.5+0.031 X ; R^{2}=-1.93$; Total fish production: $E s t=10+0.442 X ; R^{2}=0.894$ and Prediction Model total fish demand: $Y($ est. $)=15+0.211 X ; R^{2}=0.996$. The models will help fishery professionals responsible for planning and development of this sector by the way for identification and optimum utilization of various resources with appropriate measures for fisheries development of the state of West Bengal.
\end{abstract}

\section{Introduction}

Fishery is the oldest and most important livelihood option for the inhabitants of the coastal line of the country since times immemorial. This natural resource along with the marine environment has been the custodian of livelihood security of the coastal populace. Fisheries are next to agriculture in terms of providing employment and food supply. Fish is an important source of quality protein and cheaper in cost compared to another source of animal protein. About 35\% of Indian population is fish eaters and the per capita consumption is 9.8 $\mathrm{kg}$ whereas the recommended intake is $13 \mathrm{~kg}$. The uncertainties make it imperative that the resources have to be scientifically developed, monitored and managed. Development of the resources should comprise measures to augment the abundance level of the resources, strategies to exploit them in such a manner that food security is ensured. The exploitation process should be economically viable and the resources conserved in a sustained manner allowing maximum potential for exploitation. This calls for strategic planning based on scientific assessment of trends of various resources and production statistics.
It is well known that a good statistical system is essential for decision making and forming viable public policies. A lot of statistics is available from statistical hand books published by international organizations like FAO-FISHSTAT [1], and West Bengal and Govt. of India covering various aspects of fishery resources, production, consumption, resource utilization etc. [2-4]. Few reports are available on modeling in fisheries and aquaculture [5-8]. but statistical analysis to unearth hidden facts is rare in case of for West Bengal. Therefore, for the first time, it is attempt has been made to carryout in depth analysis fishery resource and production statistics trends of West Bengal a major fish producing state of India with highest per capita consumption. Demand, and Production statistics are also subjected to statistical analysis to unearth hidden facts and trends out of the data. Social impact of this sector like resource utilization, employment and earning is also presented. This will also pave the way for identification and optimum utilization of various resources with appropriate measures for fisheries development of the state of West Bengal 


\section{Methodology}

This communication is based on secondary data available so far on various aspects of fishery statistics mainly published in hand book of Fishery statistics of Government of West Bengal, Govt. of India, and FAO. The raw data is compiled, analyzed, interpreted and presented in the form of tables, graphs, and charts for easy visualization and comprehension. Various statistical methods like, descriptive statistics, correlation, regression, test statistics, trend line fitting-test, F-test etc. were performed using SPSS (16.0) and MS Excel, Trend lines with time series data on resources, production, import etc. are also fitted for model building and forecasting.

\section{Results and Discussions}

Secondary data collected from reliable Government sources are tabulated, analyzed and presented in the most convenient way for comprehension for decision making by policy planners responsible for management of this sector $[1,3,4]$.

\section{Marine fisheries resources of west bengal}

West Bengal is having a vast coast line of $158 \mathrm{~km}$. Continental shelf is vast to the extent of 17049 sq. km. Offshore area is 1813 sq.km. and inshore area up to 10 fathom depth is 777 sq. $\mathrm{km}$.Marine fisheries is an important sector of the nation's as well as West Bengals economy supporting the livelihood of the millions of fisher-folks inhabiting the long coastline of India and those who are engaged in the related activities. The marine fisheries sector of India's maritime state of West Bengal has witnessed a phenomenal growth during the last five decades both quantitatively and qualitatively with a slower growth rate presently. Therefore, attention is given for development of Inland fishery resources.

\section{Distribution of inland fishery resources of west bengal}

Total area under of River, Canal/Khal and Beal/Boars of West Bengal is 279569.31 ha. River occupies $58 \%$ of total area followed by canal/Khal (27\%) and Beal/boar (15\%). This needs attention for taking care of riverine fisheries for development as because a lot of fishermen are earning their livelihood from these open water resources. Inland fisheries enjoy prime of place in Indian economy. It provides employment and livelihood for fishers who solely depend on it.

\section{Inland fishery resources utilisation by type of fishery of west bengal}

There are two important sectors in Fisheries namely, Marine Fishery and Inland Fishery. Both sectors play an important role in West Bengal's economy. West Bengal is rich in Inland Fishery Resources. Ponds / tanks dominate with 90.62 parent resources under culture. Overall $87.56 \%$ of total potential resource is utilized for culture leaving another $12.44 \%$ for bring under culture. West Bengal is rich in open water system like reservoirs, rivers, canals and estuaries. Blue colored space is the area that can further be utilized for culture (Figure 1).

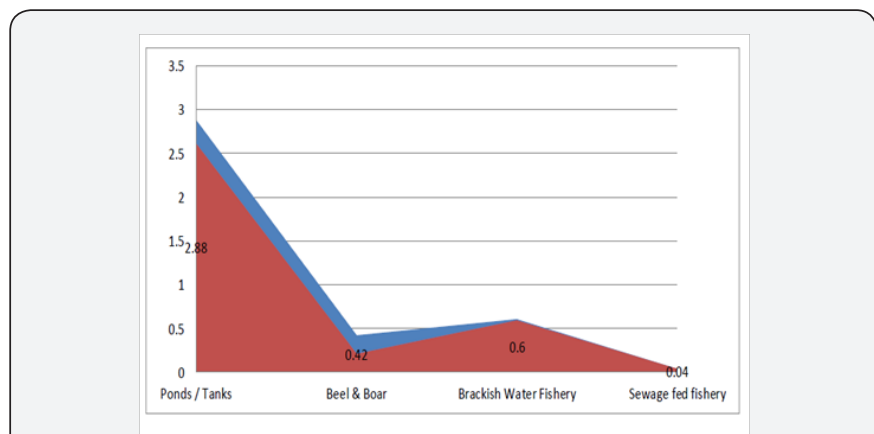

Figure 1: Potential Inland Fishery Resource by types and Area under Culture in West Bengal.

\section{Development of models for forecasting fish production of west bengal}

The emphasis in this section is on time series analysis and forecasting. A time series is a collection of data recorded over a period viz., yearly. In the present case data are available on yearly basis for Fish Production, Seed production, Import-Export data of West Bengal since 1985 and the annual production of fish since 1970-71. A time series data can be used by management to make current decisions and plans based on long-term forecasting. We usually assume past patterns will continue. Forecasting the level of production both short-term and longterm is practically dictated by the very nature of production organizations. Forecasting helps competition for the consumer's earning, stress on earning a profit for the stakeholders, a desire to procure a larger share of the market, and the ambitions of executives are some of the prime motivating forces in business.

Trend of growth performance of fish production in west bengal from $6^{\text {th }}$ to $12^{\text {th }}$ Plan

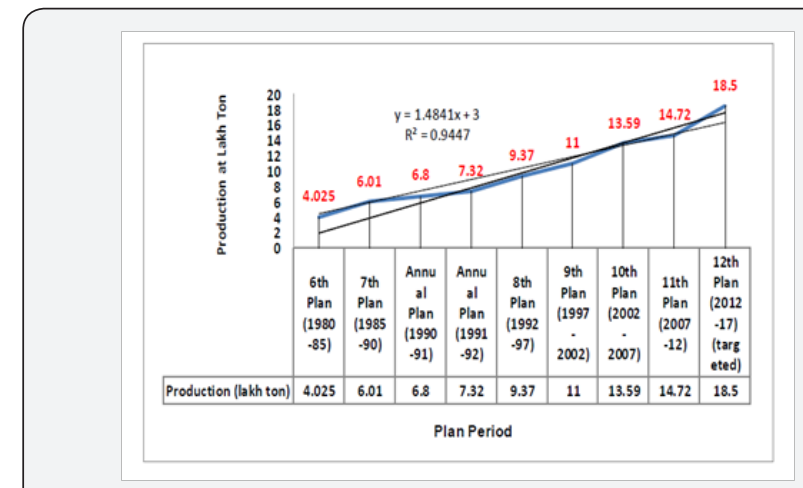

Figure 2: Trend on Growth Performance of fish production.

Model Development: It is worth noting that fish production showed a continuous increase during plan periods $\left(6^{\text {th }}\right.$ to $12^{\text {th }}$ plan) registering an increase of 14,475 lakh ton from 4,025 to18.5 lakh ton i.e. about six times (Figure 2). To quantify growth performance of fish production over the successive plan periods fitted trend line with the existing $6^{\text {th }}$ to $12^{\text {th }}$ plan period data. The fitted equation is $\mathrm{Y}$ (est.) $=1.484 \mathrm{X}\left(\mathrm{R}^{2}=0.944\right)$ where $\mathrm{Y}$ (est.) is estimated fish production and $\mathrm{X}$ is the plan periods. $\mathrm{R}$ value 
of 0.944 indicates a very good fit of the equation. That means $94.4 \%$ variability of production is explained by the equation. In the present case, a forecast a statement of the goals of management is necessary to have the raw materials, production facilities, and staff available to meet the projected demand. The fitted equation, being first of its kind in the state of West Bengal will help fishery professionals responsible for planning and development of this sector.

\section{Trends in growth of pond fisheries in west bengal}

The scenario of fish production from marine sector is declining during successive years in west Bengal and this trend is not different from the global trend. 'The State of World Fisheries and Aquaculture 2008' concludes that developments in world fisheries and aquaculture during recent years have continued to follow the trends that were already becoming apparent at the end of the 1990's capture fisheries production is stagnating and aquaculture output is expanding faster than any other animal-based food sector. There are growing concerns with regard to safeguarding the livelihoods of fishers as well as the sustainability of both commercial catches and the aquatic ecosystem from which they are extracted. To combat the scenario, the Govt. of West Bengal has taken steps to develop pond fishery and Jhora Fishery as shown in the Figure 3 below.

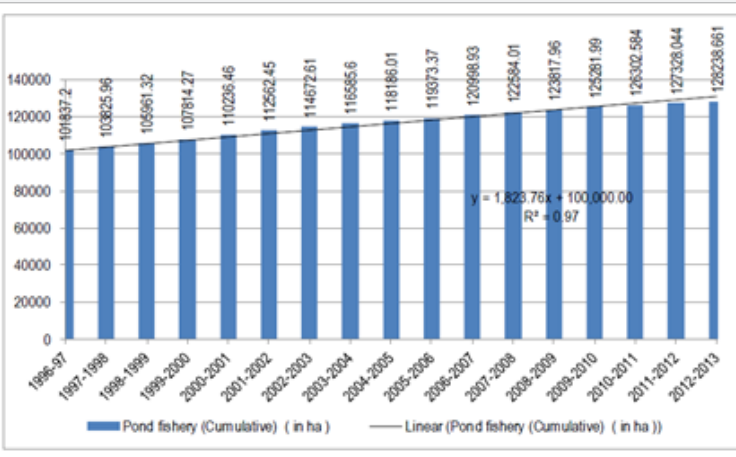

Figure 3: Trends in Pond Fishery Development (ha) during 1996-2013 in West Bengal.

One of the most important reasons for doing time series analysis is to try to forecast future values of the series. A model of the series that explained the past values may also predict whether and how much the next few values will increase or decrease. The ability to make such predictions successfully is obviously important to any scientific field. In the present case, the fitted equation is $\mathrm{Y}(\mathrm{est})=1823.76 \mathrm{X}+1000,000$ where $\mathrm{Y}$ is estimated pond fishery(ha) and $\mathrm{X}$ is year. The $\mathrm{R} 2$ value is indicative of good fit of the equation. This prediction equation may give picture of future development of pond fishery development initiated by Govt. of West Bengal.

Similarly, in case of Jhora fishery, the fitted equation is $\mathrm{Y}=165.4 \mathrm{X}+2000$ where $\mathrm{Y}$ is estimated units of Jhora fishery and $\mathrm{X}$ is year. This prediction equation gives a clear trend of development of Jhora fishery initiated by Govt. of West Bengal (Figure 4).

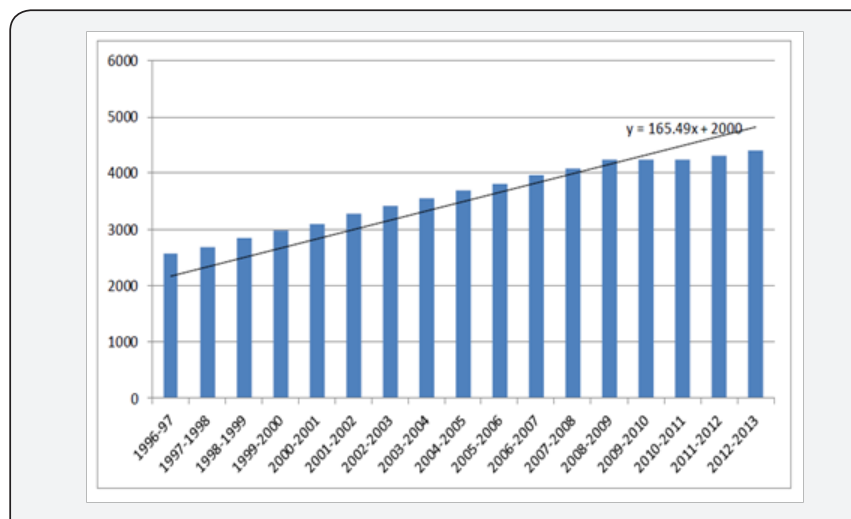

Figure 4: Trends in Units of Jhora fishery (1 unit = $140 \mathrm{Sq} \mathrm{m})$ developed during 1996 to 2013.

\section{Establishment of prediction models for demand and production of fish in west bengal}

Demand supply scenario: Fish Demand and Supply Scenario during 2007-08 to 2012-13 is presented in Figure 5. It is evident from figure that there is a steady rise of demand of fish but production is fluctuating over the years (Figure 5). Under the situation it is thought appropriate to quantify the exact nature of fluctuation trend of each of the demand and supply separately. Further, it is assumed that a model of the series that explained the past values may also predict whether and how much the next few values will increase or decrease. The ability to make such predictions successfully is obviously important to any scientific field. In the present case demand of fish being a time series set of observations obtained by measuring demand of fish -a single variable regularly over a period 2007 to 2013 .

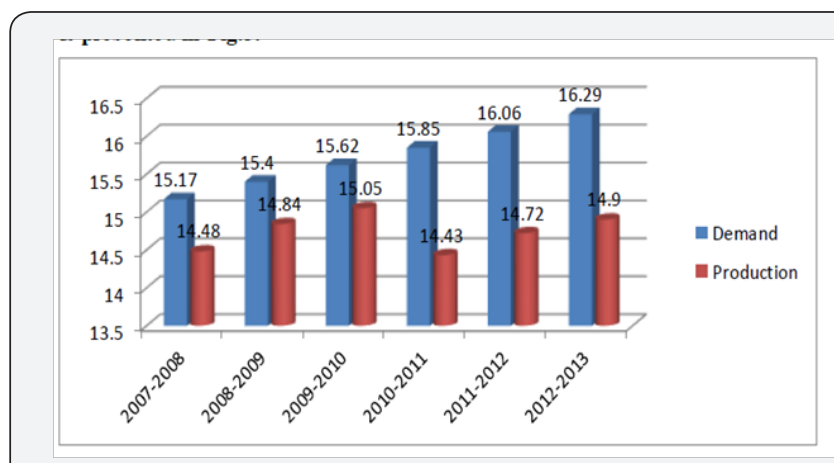

Figure 5: Fish Demand and Supply Scenario during 2007-08 to $2012-13$

Forecasting on demand of fish: As the demand of fish is increasing steadily over the years (Figure 5). The present, statistical techniques, to fit an equation capable of forecasting, are used on future demand of fish for West Bengal. The fitted equation is as follows $\mathrm{Y}$ (est.) $=15+0.211 \mathrm{X}$ (where $\mathrm{Y}$ is demand of fish in lakh ton and $\mathrm{X}$ is time in years. The $\mathrm{R} 2$ value is worked 
out as 0.996 which is an indicator of goodness of fit of the data (Figure 6). Now demand can be precisely estimated for future years simply putting the value of X (year). This model is first of its kind with fisheries sector at West Bengal that in turn help management future planning of fisheries / aquaculture sector to fill the gap of demand and supply.

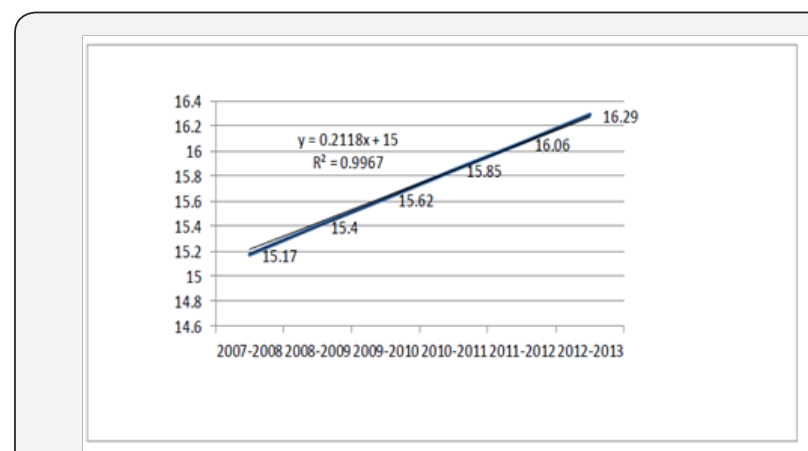

Figure 6: Linear Trend of Yearly Demand of Fish (Lakh Ton) at West Bengal.

Forecasting of fish production of west bengal: This section deals with the use of time series data at West Bengal to forecast future events. Forecasts are not always correct. The reality is that a forecast may just be a best guess as to what will happen. There are four components to a time series: the trend, the cyclical variation, the seasonal variation, and the irregular variation. The long-term trends of fisheries data follow linear trend patterns. Some move steadily upward, others decline, and still others stay the same over time. Therefore, secular trend is appropriate with the available data. We fitted trend lines for each of Inland, Marine and total Production of Fish (lakh ton) of West Bengal for the years 2000-2001 to 2012-2013 as depicted in the following Figure 7.

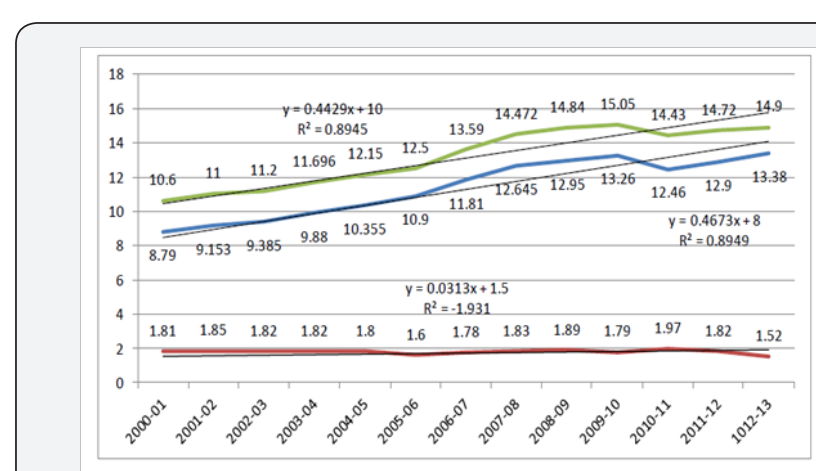

Figure 7: Trend lines of Inland, Marine and total Production of Fish (lakh ton) at West Bengal.

Least squares method: In the simple linear regression, the least squares method is used to find the best linear relationship between two variables. In forecasting methods, time is the independent variable and the value of the time series (yearly production of fish from each of the inland, marine \& total) is the dependent variable. Linear equation of the form $Y=a+b X$, was assumed based on scatter plot. For fitting the equations, the values of the slope $b$ and $a$ the intercept, were estimated from the time series data enabling the fit of the linear trend equations.

Now the fitted Equations after putting the estimated values a \& b from the respective data was established are as follows:

Prediction Model Inlandfish production : $Y_{\text {est. }}=8+0.467 X, R^{2}=0.894$

Prediction Model Marinefish production $Y_{\text {est. }}=1.5+0.031 X, R^{2}=-1.93$

Prediction Model Totalfish production $: Y_{\text {est. }}=10+0.442 X, R^{2}=0.894$

Where $Y_{\text {est. }}$ is the estimated values inland / marine / total fish production (dependent variable) and $\mathrm{X}$ is time in years (independent variable).

Test of goodness of fit of the models: This section provides definitions of the goodness-of-fit measures used in time series modeling. R-squared is an estimate of the proportion of the total variation in the series that is explained by the model. This measure is most useful when the series is stationary. Positive values mean that the model under consideration is better than the baseline model. Looking at the model developed for Inland Fish Production we find $\mathrm{R}^{2}$ is 0.894 i.e. $89.4 \%$ of the variability is explained by the equation and considered to be a very good fit. Similarly, model developed for Total Fish Production explains $89.4 \%$ of variability of production as evidenced by R2 value of 0.894 . But Marine fish production depicted a negative value of $R^{2}$ $(-1.93)$ that means the model under consideration is worse than the baseline model. Now for any values of X (year) we can get the estimates of Y (Production).

This is the first attempt to develop prediction equation in case of fish production estimation of West Bengal based on time series data. Estimation of production, for marine, inland and total data approximate a linear trend, the equation developed by the least squares method can be used to estimate future values. This is based on past production data. In this time series case, there are thirteen years fish production data. Many researchers suggest that we do not project production, and other business and economic series more than $\mathrm{n} / 2$ time periods into the future where $\mathrm{n}$ is the number of data points. If, for example, there are 13 years of data, we would make estimates only up to 6-7 years into the future. Others suggest the forecast may be for no longer than 2 years, especially in rapidly changing economic times. However, forecasts are not always correct. The reality is that a forecast may just be a best guess as to what will happen.

\section{Conclusion and Recommendations}

a. Fishermen constitute about 3.3 percent of total population of 9.13 crores West Bengal.

b. Inland Fishery Resources: Ponds/tanks dominate with 90.62 percent resources under culture.

c. West Bengal is rich in open water system like reservoirs, rivers, canals and estuaries. 
Total area under of River, Canal/Khal and Beal/Boars of West Bengal is 279569.31 ha. River occupies $58 \%$ of total area followed by canal/Khal (27\%) and Beal/boar (15\%). This needs attention for taking care of riverine fisheries for development as because a lot of fishermen are earning their livelihood from these open water resources.

\section{Model development}

It is worth noting that fish production showed a continuous increase during plan periods (6th to 12th plan) registering an increase of 14,475 lakh ton from 4,025 to18.5 lakh ton i.e. about six times. During Successive Plan periods, Linear increasing Trend of fish production observed:

$Y($ est. $)=1.484 X ;\left(R^{2}=0.944\right)$

Prediction Model Inland fish production : Yest $=8+0.467 X ; R^{2}=0.894$

Prediction Model Marine fish production : Yest $=1.5+0.031 X ; R^{2}=-1.93$

Prediction Model Total fish production: Yest $=10+0.442 X ; R^{2}=0.894$

Prediction Model Total fish demand $: Y($ est. $)=15+0.211 X ; R^{2}=0.996$

\section{Impact of fishery/aquaculture on socio-economy of} West Bengal

Utilization of resources: Overall $87.56 \%$ of total potential resource is utilized for culture leaving another $12.44 \%$ for bring under culture.

Fish demand and supply scenario 2012-13: In the year 2012-2013 there is a gap of 5.2 lakh ton.

GDP contribution: Fishery sector contributes approximately 2.44 to $2.75 \%$ of GDP

Employment generation: Marine fish production is declining over the years till this sector employs $61 \%$ of fishers followed by cooperative societies, brackish water and inland fisheries. Therefore, right attention may be given to marine sector considering socio-economic aspect. Fisheries are next to agriculture in terms of providing employment and food supply. Fish is an important source of quality protein and cheaper in cost compared to another source of animal protein. Fisheries provide employment and sustenance to sizeable sections of the society in Rural west Bengal, especially weaker sections. Fisheries are a renewable natural resource, subject to its own dynamics, acted upon by various forces. Open access system of exploitation of the resources lead to overcapitalization, resulting in decrease in the yield rates and unprofitability of operations and threatening the food security as well. The concomitant uncertainties make it imperative that the resources must be scientifically developed, monitored and managed.

\section{Acknowledgement}

The authors are thankful to their respective Institutions/ Departments for encouragement and guidance in carrying out the research.

\section{References}

1. http://www.fao.org/docrep/i2727e/i2727e.pdf

2. Government of India (2002b) Tenth Five-Year Plan (2002-07), Planning Commission, New Delhi, India.

3. Hand Book of Fisheries Statistics 2012-13. Govt. of West Bengal, India.

4. Handbook on Fisheries Statistics (2014) Government of India, Ministry of Agriculture, Department of Animal Husbandry, Dairying and Fisheries, Krishi Bhavan, India.

5. Roy AK, Anil U (2014) Fisheries Resource and Production Statistics of NE States of India-An Analytical Value-Added Presentation. Narendra Publishing House, India, p. 313.

6. Roy AK (2009) Modelling in Aquaculture. In: Roy AK, Niranjan S (Eds), Modelling, Forecasting, Artificial Neural Network and Expert System in Fisheries and Aquaculture. Daya Publishing House, Delhi, India.

7. Roy AK, Sarangi N (2009) Modeling, Forecasting, Artificial Neural Network and Expert system in Fisheries \& Aquaculture, Daya Publishing House, New Delhi, India.

8. Upadhyay AD, Roy AK, Jumli K (2012) Exploratory Data Analysis Approach with Fish and Seed Production in Arunanchal Pradesh. Keanean Journal of Science 1: 22-25.

\section{Your next submission with Juniper Publishers} will reach you the below assets

- Quality Editorial service

- Swift Peer Review

- Reprints availability

- E-prints Service

- Manuscript Podcast for convenient understanding

- Global attainment for your research

- Manuscript accessibility in different formats

( Pdf, E-pub, Full Text, Audio)

- Unceasing customer service

Track the below URL for one-step submission https://juniperpublishers.com/online-submission.php 